\title{
Untreated Metastatic Squamous Cell Carcinoma to Neck with Occult Primary
}

National Cancer Institute

\section{Source}

National Cancer Institute. Untreated Metastatic Squamous Cell Carcinoma to Neck with

Occult Primary. NCI Thesaurus. Code C115917.

A finding of metastatic squamous cell carcinoma to neck with occult primary that has not been treated. 